\title{
Organic farming in West Virginia: A behavioral approach
}

\author{
James R. Farmer, ${ }^{\mathrm{a}, \mathrm{b} *}$ Graham Epstein, ${ }^{\mathrm{b}, \mathrm{c}}$ Shannon Lea Watkins, ${ }^{\mathrm{c}}$ and Sarah K. Mincey ${ }^{\mathrm{c}}$
}

Indiana University

Submitted January 13, 2014 / Revised March 11 and April 14, 2014 / Accepted April 18, 2014 /

Published online September 5, 2014

Citation: Farmer, J. R., Epstein, G., Watkins, S. L., \& Mincey, S. K. (2014). Organic farming in West

Virginia: A behavioral approach. Journal of Agriculture, Food Systems, and Community Development, 4(4),

155-171. http://dx.doi.org/10.5304/jafscd.2014.044.007

Copyright (C) 2014 by New Leaf Associates, Inc.

\begin{abstract}
Although organic production continues to expand and remains the fastest growing segment of the U.S. agricultural economy, demand for organics continues to outpace supply, causing a lag in the supply chain. One of many important elements to remedying this issue is for more farmers to adopt organic practices and/or transition to organic
\end{abstract}

* Corresponding author: James R. Farmer, Indiana University; 1025 East 7th Street; Bloomington, Indiana 47405 USA;

+1-812-856-0969; jafarmer@indiana.edu

a School of Public Health, Indiana University; Bloomington, Indiana USA.

b Vincent and Elinor Ostrom Workshop in Political Theory and Policy Analysis, Indiana University, Bloomington, Indiana USA.

${ }^{c}$ School of Public and Environmental Affairs, Indiana University; Bloomington, Indiana USA.

Disclosures: This project was funded by the USDA NIFAOREI Cooperative, award \#2011-51300-30709. The lead author is a reviewer for the Journal of Agriculture, Food Systems, and Community Development. certification. One state well positioned to tap into eastern U.S. metro markets is West Virginia. Our study sought to understand the factors affecting West Virginia farmers' decision to farm organically, as well as the barriers limiting pursuit of certification. Though West Virginia has the highest number of small farms in the U.S., only five farms were USDA organic-certified in 2012. We used a mixed-methods approach to explore the barriers to implementing organic practices and pursuing organic certification. The methods included interviews and mailed surveys, garnering responses from more than 230 farmers in West Virginia. We applied a social-ecological system lens for the development of a statistical model to parse out the major variables affecting transition to organic methods. Our results suggest that the decision to farm organically is largely an economic one, with a lack of perceived benefits being nearly as influential as perceived constraints as barriers. We also found that social ties to certified organic farmers reduced the likelihood of others implementing organic production practices. Finally, we propose that the 
choice to farm organically and pursue organic certification be studied in a holistic manner that assesses motives, constraints, and barriers to implementing organic practices in conjunction with relevant contextual attributes (farm characteristics and personal demographics) that affect the decision-making process.

\section{Keywords}

organic agriculture, sustainable agriculture, farming, USDA, certified organic, West Virginia, central Appalachia

\section{Introduction}

Over the past 40 years, conservationists, environmental advocates, and sustainable farmers and agricultural professionals have promoted the environmental and health benefits of organic agriculture. Empirical evidence supports these efforts and shows that organic techniques tend to reduce the incidence and magnitude of deleterious environmental impacts associated with conventional agriculture (Hole, Perkins, Wilson, Alexander, Grice, \& Evans, 2005; Pimentel, Hepperly, Hanson, Douds, \& Seidel, 2005; Reganold, Glover, Andrews, \& Hinman, 2001; Wortman, Francis, Bernards, Drijber, \& Lindquist, 2012). There remains considerable potential for increasing the market share of organic products within the United State food system. Organic production experienced doubledigit annual growth in sales (15 percent to 21 percent) between 1999 and 2009, making it the fastest-growing U.S. agricultural sector (Dimitri \& Oberholtzer, 2009; Kuminoff \& Wossink, 2010). In 2010, organic products generated approximately US $\$ 28.6$ billion in U.S. sales (Organic Trade Association [OTA], 2011), and the results from several studies suggest that unabated growth in demand continues to outpace the supply of organic products (Constance \& Choi, 2010; Cranfield, Henson, \& Holliday, 2010; Thilmany, 2006). It is therefore somewhat surprising that more farmers have not pursued organic farming as a strategy to potentially improve their financial well-being.

To understand the factors affecting organic production, we need to develop a better understanding of the circumstances and conditions that facilitate the decision to adopt or convert to organic practices and the decision to complete the USDA organic certification process. Accordingly, our research is oriented around two distinct but related questions:

- First, what factors influence a farmer's decision to adopt organic production methods?

- Second, how do farmers perceive USDA organic certification, and what limits their pursuit of certification?

We analyzed farmers' production choice by applying survey data to institutional models of decision-making (Crawford \& Ostrom, 1995; Gintis, 2009; Ostrom, 1998) and complex socialecological systems (Ostrom, 2007, 2009; Ostrom \& Cox, 2010) that collectively reveal the importance of normative motives and the social-ecological context in which decisions are made. Considering this literature, we ask how economic, normative, and social motives affect the likelihood of choosing to farm organically given a set of relevant contextual attributes (e.g., age, education, agricultural training, farm size, setting grew up in).

\section{A Complex Systems Approach to the Study of Organic Farming}

While individual differences between organic and conventional farmers are interesting, as of yet, little research has confronted the question as to how social, economic, environmental value, risk perception, and contextual factors jointly influence production choices. More specifically, studies of organic farming choices tend to compare conventional and organic farmers on isolated factors that are likely to have inconclusive results, rather than building a more inclusive model of factors that might affect farming choice. Agricultural production choices in social-ecological systems in turn are better conceived of as the product of a complex bundle of social, ecological, and institutional factors and their interactions that combine to influence those choices. Thus we argue that greater engagement with a social-ecological systems lens (Basurto \& Ostrom, 2009; Ostrom, 2009) may help uncover relationships between motives, context, and organic production. 
Previous Evidence of Factors Affecting

\section{Choice to Farm Organically}

The choice to adopt organic farming practices has been studied in a variety of settings, although much of this work has examined the transition from conventional to organic agriculture outside of the United States (Uematsu \& Mishra, 2012) and much of it is qualitative. Previous quantitative work has tended to estimate correlations between production and factors such as farm economics, risk, and environmental concern, and contextual factors such as a producer's experience, age, and gender (Darnhofer, Schneeberger, \& Freyer, 2005), without considering the larger context in which farmers are making decisions.

This previous work demonstrates that many motivations are consistent across country, continental, and cultural lines. Environmental concerns and pollution issues surrounding industrialized agriculture have been found to facilitate the conversion to organic production both in Europe and North America (Sullivan, Mccann, de Young, \& Erickson, 1996; Svensson, 1991). Interest in farm profitability and financial concerns also influence farmers' decisions whether to transition to organic (Henning, Baker, \& Thomassin, 1991; Padel, 2011). Furthermore, health concerns, be they for the farmer, family, community, or consumer, also appear to factor into the decision to convert to organic production (Fairweather, 1999; Hall \& Mogyorody, 2001). Additionally, personal incidents of environmental health "tragedies" often influence farmers' decisions to transition to organic production (Brophy et al., 2012). Research on certified and noncertified organic farmers also highlights demographic differences between organic producers and conventional farmers, namely age, gender, and size of operation (Burton, Rigby, and Young, 1999; Hall \& Mogyorody, 2007; Walz, 2004).

Economic factors such as economies of scale, price premiums, and access to organic markets (both retail and wholesale) play an important role in the choice to adopt organic farming practices (Veldstra, Alexander, \& Marshall, in press) or to pursue USDA organic certification (Richards, Acharya, \& Molina, 2011; Torres, Marshall, \& Alexander, 2013). These economic factors can be divided into two instrumental motives: (1) perceived economic benefits (de Buck, van Rijn, Roling, \& Wossink, 2001) and (2) perceived economic costs of change (Kuminoff \& Wossink, 2010). Klonsky (2012) found that a decrease in crop yield and an increase in production costs for several organically grown specialty crops in comparison to their conventionally grown counterparts necessitate a market price premium for organics to make up the difference in profit. This is very much crop-dependent, as noted by Reganold et al. (2001), who found organic apple production systems to produce superior economic returns when compared to integrated and conventional approaches. Another cost barrier is human capital (time). Sierra, Klonsky, Strochlic, Brodt, and Molinar (2008) found that among former USDA organic-certified California farmers who chose to decertify, their operational costs - paperwork, record-keeping, and certification - were the most influential factor in this decision.

Research on farmers using organic practices tends to suggest that they are more likely to assume risks (Gardebroek, 2006; Hardwaker, Huirne, Anderson, \& Lien, 2004) and are more concerned about the environmental effects of their farm management choices than are conventional farmers (Veldstra et al., in press). Koesling, Ebbesvik, Lien, Flaten, Steiner, and Arntzen's (2004) study found that certified and noncertified organic farmers were more likely to take risks than conventional farmers, noting significant difference between the two groups on production methods, marketing approaches, and finance and investment decisionmaking. Koesling et al. (2004) also found that farmers more involved in grain production shared a greater perception of risk in relation to institutional systems and/or sources than specialty-crop farmers.

In addition to instrumental motives, previous work suggests a role for normative motives in production choice. For our study, normative motives broadly consist of personal moral valuations that are expected to emphasize the philosophical environmental aspects of organic farming (Svensson, 1991) and social norms that tend to generate incentives supporting an individual to conform to his or her community (Posner 
1997; Ramcilovic-Suominen \& Epstein, 2012). Darnhofer, Schneeberger, and Freyer's (2005) assessment of the decision to convert to an organic farming system in Austria builds from Fairweather's (1999) classification of farmers (noting organic farmers as "committed" or "pragmatic" and conventional farmers as "hopeful organic," "frustrated organic," or "do not grow organic"), noting that 85 percent of the organic farmers in their study chose the practice based on their environmental convictions. This group of Austrian farmers tended to place economic considerations secondary to their foundational philosophy on farming. In a recent study of organic dairy farmers in Canada, Cranfield et al. (2010) found that environmental motives superceded economic drivers, which the literature often notes as paramount. Building from Cranfield et al.'s (2010) suggestion, our study collected data from farmers employing both conventional and organic farm management practices to provide insight concerning their choices.

Social norms are noted throughout a variety of environmental literature as having consequential impacts on the adoption of pro-environmental behaviors and decisions (Läpple, 2012; RamcilovicSuominen \& Epstein, 2012). Close association, strong networks, and a high degree of social integration with others performing the behavior are all components that can profoundly affect behavior adoption (DeSouza Filho, Young, \& Burton, 1999). Läpple's (2012) survey of organic, former organic, and conventional farmers in Ireland found a significant difference between groups and their association with other organic farmers. Conventional farmers tended to socialize less with organic farmers than the other two groups.

\section{Study Site}

This research was conducted in the state of West Virginia, located in the Appalachian region of the southern United States. West Virginia is the least populous southeastern state, with an estimated population of 1,855,413 in 2012 and a relatively low median household income of US $\$ 38,482$ in 2011, ranking it forty-ninth of the fifty states in terms of household income. West Virginia is dominated by forested mountains, a challenging landscape for row-crop agriculture. Agricultural areas, however, are found throughout the state as the sloping topography lends itself to orchards and other types of fruit production as well as to the production of livestock and specialty crops as defined by the USDA. ${ }^{1}$ West Virginia is an appropriate site for the study of variables affecting farmers' decisions to adopt organic practices, due to its plethora of small farmers, juxtaposition to major markets, and topography that is more conducive to growing specialty crops and raising livestock than traditional commodity row crops. West Virginia has the highest percentage of small farms of any U.S. state, with a total of 23,618 farms that average 157 acres (64 ha) per farm, whereas the average U.S. farm is 418 acres (169 ha) (U.S. Department of Agriculture [USDA], 2007a). West Virginia was also one of 22 states that saw a 5.1 percent or greater increase in the number of farms from 2002 to 2007 (USDA, 2007a). According to the USDA (2007b) Agricultural Census, 52.5 percent of farms in West Virginia earned less than US $\$ 2,500$ and 67.7 percent earned less than US\$5,000 annually. The average age of a West Virginia farmer was 58.1, and 99.76 percent of them identified themselves as white. Females are the primary operator of approximately 13.6 percent of farms. Over 65 percent of West Virginia farmers hold an off-the-farm job. Nearly 47 percent had Internet access on the farm.

\section{Methods}

\section{Research Design}

Our study had two primary research questions: (1) what factors influence a farmer's decision to adopt organic production methods? and (2) how do farmers perceive USDA organic certification and what limits their pursuit of certification? We used a two-phase sequentially embedded mixed-methods research design as outlined by Creswell and Plano

\footnotetext{
${ }^{1}$ According to the USDA, specialty crops are, "fruits and vegetables, tree nuts, dried fruits, horticulture, and nursery crops (including floriculture). Eligible plants must be intensively cultivated and used by people for food, medicinal purposes, and/or aesthetic gratification to be considered as specialty crops" (USDA, 2013).
} 
Clark (2007) and similar to Cranfield et al.'s (2010) design for their study of organic farmers in Canada. First, interviews were conducted with 14 farmers in West Virginia in order to develop a relevant questionnaire that was then administered to farmers in West Virginia. ${ }^{2}$ The sequential approach allowed for important refinements of research instruments to the target population, while mixed methods (interviews and survey administration) allowed for greater breadth in data collection (Greene, Caracelli, \& Graham, 1989). This paper presents the results of the phase 2 survey data.

\section{Survey and Analysis Methods}

Survey development and administration. We developed a questionnaire based on analysis of interview data and a literature review. The questionnaire had five sections. ${ }^{3}$ Section 1 sought operational information, while section 2 contained questions and prompts that pertained to production methods and farming philosophy, and risk perception prompts that were based on those of Koesling et al. (2004). Section 3 gathered details on market variables and distribution outlets, farmers' perception of demand for certified organic products in their area, and distribution venues. Section 4 solicited data and perspectives on USDA organic certification and the process. Section 5 included demographic questions. The questionnaire underwent review and revision, with comments solicited from scholars and an expert panel composed of conventional, organic, and specialtycrop farmers.

To develop a survey recipient list, the research team used a variety of mechanisms to compile a list of West Virginia farmers focused on specialty crop and animal production. A participant list from a conference organized by the West Virginia Small Farm Center supplied the greatest number of contacts. This was supplemented with contact information from online databases and solicitations to state and regional agricultural groups. Our contact list was developed to include only those West

\footnotetext{
${ }^{2}$ A detailed reporting of all of the methods and the interview results can be found in Farmer, Peters, Hanson, \& Boettner (2013).

${ }^{3}$ The full questionnaire is available in Farmer et al. (2013).
}

Virginia farmers primarily engaged in the production and distribution of specialty crops, animal products, and nontimber forest products, as opposed to traditional commodity row-crop farmers. That said we undoubtedly missed a number of potential farmers and our lack of access to a complete list of West Virginia farmers does limit the generalizability of our results and weakens the conclusions that can be made.

To garner the highest possible response rate, we employed a modified Tailored Design Method for the distribution of the mailed questionnaire (Dillman, Smyth, \& Christian, 2009). Mailing 1 occurred on January 25, 2012, with the fourth and final mailing distributed on February 14, 2012. As completed questionnaires were returned, data were entered into a Qualtrics (Qualtrics, LLC) online survey form in order to decrease the number of input errors that may occur when using a traditional spreadsheet system.

Survey Analysis. A behavioral approach to the study of the organic farming decision-making process begins with the general hypothesis that individuals will invest in change (in this case, adopt organic practices) as the perceived benefits of organic farming increase relative to conventional alternatives (Basurto \& Ostrom, 2009; Poteete, Janssen, \& Ostrom 2010). It must be noted that although this general hypothesis constitutes the core of this investigation, it is not tested in this research. Rather, it is assumed and used to construct an empirical model of the motives and contextual attributes that influence the choice to adopt organic farming practices. In accordance with the organic farming and environmental decision-making literature previously identified and discussed, our approach analyzes the data based on five types of motives (including both instrumental and normative categories) that may influence the perceived utility of organic farming: (1) perceived economic benefits, (2) perceived economic costs of change, (3) general risk tolerance, (4) personal moral valuations of the alternatives that are expected to emphasize the environmental aspects of organic farming, and (5) social norms that tend to generate incentives supporting conformity. Thus, the adoption of organic farming practices 
would be predicted to increase with growing levels of environmental concern, perceived benefits, risk tolerance and socialization with organic farmers. Decline in adoption of organic practices would be attributed to perceived increase in economic constraints and inadequate knowledge or skill needed to implement organic production. In other words, choice to adopt and continue use is a function of the motives conditioned on the context.

We employed a variety of statistical analyses to compare the two groups (noncertified organic farmers vs. conventional farmers), including simple descriptive statistics, analysis of variance (ANOVA), and chi-square. To assess the factors associated with the choice to pursue organic farming practices, we built a predictive (logistic) model using the social-ecological systems framework that includes a set of instrumental and normative motives and potentially relevant contextual attributes. The dependent variable is a binary (twopart) measure that indicates whether a farm uses conventional farming practices (0), or organic techniques (1). Independent variables incorporated into the logistic regression models (a statistical analyses that shows the relationship between several variables) included previous agriculture training, educational attainment, age, where one grew up, farm size, percent of income provided by farm sales, years farming, overall income, gender, and off-the-farm employment, all of which are summarized in Table 1. With the exception of socialization, each motive is an indicator composed of three Likert-scale items. Each motive was measured using a principal component factor analysis to see how variables were linked and related. Each set of items converged on a single-factor solution that accounts for a minimum of 68.7 percent of the common variance.

We estimate three separate logistic (predictive) regression models. The first model was chosen as a function of the five motives we predicted to directly affect the perceived utility of organic farming. The second and third models consider the context in which a decision is made by including theoretically relevant contextual attributes. $\mathrm{Al}$ though model 1 is the most conservative, it ignores relevant covariates and likely suffers from omitted variable bias. Model 2 includes all the theoretically relevant motives and retained contextual attributes on the basis of a backwards selection $(p<0.2)$ in an attempt to offset the relative weaknesses of each. Model 3, which includes a wider range of potentially influential attributes, faces more significant statistical power constraints due to the inclusion of so many variables.

\section{Results}

Questionnaires were mailed to 884 potential participants. Among the mailed questionnaires, 65 were returned for insufficient addresses, and 68 were returned because the recipient no longer qualified to participate in the study. Thus, 751 addresses were deemed valid. We received 219 useable surveys, a 29.2 percent response rate. Participants left some questions blank; therefore there are fewer than 219 responses for certain questions. Respondents initially were classified according to membership in one of four categories: conventional farmers $(n=120)$, those in transition to USDA organic certification $(n=5)$, noncertified organic farmers $(n=91)$, and organic exempt (those following all National Organic Program standards but who have gross sales less than US $\$ 5,000$ per year) $(n=3)$. Farmers in transition, noncertified organic, and organic exempt were grouped $(n=99)$ based on general similarities in management practices and were compared to their conventional counterparts. Sample sizes of farmers in transition and organic exempt were too small to statistically compare to the noncertified organic farmers. Given that all three groups are practicing organic methods, but are not currently certified, we labeled them noncertified organic farmers (NCOF). The five certified organic farms in West Virginia were not included in the grouping in order not to confound the analysis.

The survey results are presented in three main subsections. First, farm details and respondent demographics are provided. Analysis and corresponding results that answer the first research question are then given, followed by that for the second. 
Survey Results

Respondent characteristics. The demographic results comparing conventional farmers (CF) and $\mathrm{NCOF}$ are presented in Table 2, providing an overview of farmer characteristics (percentages given in percent of valid responses). More than half of the respondents used conventional methods (54.7 percent $/ n=120)$, while 45.2 percent $(n=99)$ used organic methods but were not USDAcertified organic. Additionally, 2.7 percent of participants indicated that they had once been USDA-certified organic and that they had let their certification expire. These individuals still maintained organic management practices.

The median acres farmed was 20 (8 ha), and 84.9 percent of farmers owned all of their land. The responsibilities for running the farming opera- tions generally fell to both males and females, with 48.9 percent of respondents noting men and women share the responsibilities, 37 percent noting that only males hold the responsibility, and 11.4 percent noting that only females hold this responsibility. Almost three-quarters of respondents (72.6 percent) reported having Internet access on the farm, with 55.7 percent indicating that they use it for farming operations. Respondents reported both their gross and net farm income, with approximately one-third of respondents having grossed US $\$ 2,500$ or less, and about one-half grossing US $\$ 5,000$ or less. Net income, as expected, is skewed even lower; approximately 60 percent of respondents report a net income of US $\$ 5,000$ or less. When asked whether they use USDA programs such as the Environmental Quality Incen-

Table 1. Description and Summary Statistics of Parameters Included in Logistic Regression Models $(N=141)$

\begin{tabular}{|c|c|c|c|c|c|c|}
\hline Variable & Description & Mean & Std. Dev. & Median & Minimum & Maximum \\
\hline Organic practices & $\begin{array}{l}\text { Adoption of organic practices } \\
(1=\text { Yes; } 0=\text { No) }\end{array}$ & 0.49 & 0.50 & 0 & 0 & 1 \\
\hline Environmental concern & $\begin{array}{l}\text { Composite measure of environmental } \\
\text { concern }\end{array}$ & 0.00 & 0.96 & 0.41 & -4.73 & 0.63 \\
\hline Economic constraints & $\begin{array}{l}\text { Composite measure of perceived } \\
\text { economic constraints }\end{array}$ & 0.00 & 0.98 & 0.20 & -2.40 & 1.50 \\
\hline Economic benefits & $\begin{array}{l}\text { Composite measure of perceived } \\
\text { economic benefits of organic farming }\end{array}$ & 0.00 & 0.97 & -0.07 & -1.24 & 1.74 \\
\hline Risk tolerance & $\begin{array}{l}\text { Composite measure of general risk } \\
\text { tolerance }\end{array}$ & 0.00 & 0.97 & 0.17 & -3.40 & 1.24 \\
\hline Socialize & $\begin{array}{l}\text { Level of socialization with organic } \\
\text { farmers ( } 1=\text { Low; } 7=\text { High) }\end{array}$ & 3.91 & 1.71 & 4 & 1 & 7 \\
\hline Gender & $\begin{array}{l}\text { Female decision-maker } \\
(1=\text { Primary or shared; } 0=\mathrm{No})\end{array}$ & 0.62 & 0.49 & 1 & 0 & 1 \\
\hline Income (US\$) & $\begin{array}{l}\text { Household income } \\
(1=\$ 0-\$ 19,999 ; 6=\$ 100,000+)\end{array}$ & 3.48 & 1.55 & 3.00 & 1 & 6 \\
\hline Nonfarm employment & $\begin{array}{l}\text { Second off-farm employment (1=Yes; } \\
0=\mathrm{No})\end{array}$ & 0.62 & 0.49 & 1 & 0 & 1 \\
\hline Years & $\begin{array}{l}\text { Years of direct involvement in farming } \\
\text { operations }\end{array}$ & 16.59 & 13.41 & 12 & 1 & 55 \\
\hline$\%$ Income from farm & $\begin{array}{l}\text { Percent of income derived from } \\
\text { farming operation }\end{array}$ & 18.78 & 25.40 & 8.00 & 0 & 100 \\
\hline$\overline{\text { Size }}$ & Natural logarithm of farm size (acres) & 2.67 & 1.89 & 2.71 & -2.06 & 7.60 \\
\hline$\overline{\text { Age }}$ & Age of respondent (years) & 53.57 & 13.79 & 55 & 18 & 84 \\
\hline Urban & $\begin{array}{l}\text { Raised in urban/suburban setting } \\
(1=\text { Yes; } 0=\mathrm{No})\end{array}$ & 0.36 & 0.48 & 0 & 0 & 1 \\
\hline Bachelors & $\begin{array}{l}\text { Completed at least a bachelor's } \\
\text { degree program ( } 1=\text { Yes; } 0=\mathrm{No})\end{array}$ & 0.60 & 0.49 & 1 & 0 & 1 \\
\hline Ag. Training & $\begin{array}{l}\text { Formal agricultural training } \\
(1=\text { Yes; } 0=\text { No) }\end{array}$ & 0.43 & 0.50 & 0 & 0 & 1 \\
\hline
\end{tabular}

Note: 1 acre $=0.4$ ha 
tives Program (EQIP), Conservation Reserve Program (CRP), subsidies, or insurance, 30.6 percent of farmers indicated yes, 61.6 percent indicated no, and 7.8 percent of participants failed to respond to this question. Within West Virginia, the communities of Morgantown, Charleston, Romney, Fairmont, and Lewisburg were common points of distribution. Additionally, a limited number of farmers indicated they distribute to the Baltimore $(n=9)$ and Washington, D.C. $(n=3)$ market areas.

Research Question 1: What factors influence a farmer's decision to adopt organic production methods?

Based on chi-square results, NCOF are younger, share farm responsibilities more equally between men and women, farm smaller acreages, have attained higher levels of education, are more likely to have access to the Internet on the farm, and grew up in suburban or urban areas.

Logistic regression was used to identify the motives and contextual factors that influence the choice to adopt organic practices. The results and model diagnostics are presented in Table 3. Model 1 includes only the economic and normative motives that are presumed to directly affect choice, while models 2 and 3 include additional contextual factors. The models can be compared using the model specification statistics found at the bottom of the table, as well as a likelihood ratio test given their nested nature. In general, preferred models will have higher $\mathrm{R}^{2}$, log-likelihoods, and correctly classify a larger percentage of cases. They will also have lower AIC (Akaike information criterion) and BIC (Bayesian information criterion) values (Raftery, 1995). However, the strongest statistical guide for selecting among models comes from the likelihood ratio test that is distributed asymptotically chi-squared and can be used to compare the fit of nested models against the appropriate critical value. The results of these tests suggest that models $2(\mathrm{LR}=16.554, \mathrm{df}=5, p=0.005)$ and $3(\mathrm{LR}=23.690$, $\mathrm{df}=10, p=0.008)$ are preferred to model 1 , but that model 3 does not provide a statistically significant

Table 2. Summary Demographic Statistics and T-test for CF vs. NCOF (numbers given are valid percent of $n=219$ )

\begin{tabular}{|c|c|c|c|c|}
\hline Variable & Subvariable & $\begin{array}{c}\text { CF } \\
\text { Mean / \% }\end{array}$ & $\begin{array}{l}\text { NCOF Farmer } \\
\text { Mean / \% }\end{array}$ & $\begin{array}{l}p \text {-value } \\
\text { (ANOVA) }\end{array}$ \\
\hline Age & & 58 & 52.34 & $.006 *$ \\
\hline \multirow[t]{4}{*}{ Education } & No high school diploma & $4.2 \%$ & $1.0 \%$ & \multirow{4}{*}{$.005 *$} \\
\hline & Post-high school training & $35 \%$ & $31.3 \%$ & \\
\hline & Bachelor's degree & $23.3 \%$ & $36.4 \%$ & \\
\hline & Post-bachelor's degree & $30.8 \%$ & $24.2 \%$ & \\
\hline Off the farm job & & $57.5 \%$ & $60.6 \%$ & .542 \\
\hline $\begin{array}{l}\text { Years involved with farming } \\
\text { operation }\end{array}$ & & $\begin{array}{c}29 \text { years } \\
(\text { medan }=26)\end{array}$ & $\begin{array}{l}18.29 \text { years } \\
(\text { median }=12)\end{array}$ & $.000 * *$ \\
\hline \multirow[t]{3}{*}{ Setting grew up in } & Rural & $73.3 \%$ & $48.9 \%$ & \multirow{3}{*}{$.001 * *$} \\
\hline & Suburban & $15.0 \%$ & $36.4 \%$ & \\
\hline & Urban & $5.8 \%$ & $9.1 \%$ & \\
\hline First generation on the farm & & $56.7 \%$ & $81.6 \%$ & .639 \\
\hline \multicolumn{2}{|c|}{ \% of income from farming operation } & $19.18 \%$ & $21.5 \%$ & .621 \\
\hline \multirow[t]{6}{*}{ Household income (US\$) } & $\$ 0-\$ 19,999$ & $5.8 \%$ & $11.1 \%$ & \multirow{6}{*}{$.002 * *$} \\
\hline & $\$ 20,000-\$ 39,999$ & $12.5 \%$ & $28.3 \%$ & \\
\hline & $\$ 40,000-\$ 59,999$ & $26.7 \%$ & $22.2 \%$ & \\
\hline & $\$ 60,000-\$ 79,999$ & $11.7 \%$ & $14.1 \%$ & \\
\hline & $\$ 80,000-\$ 99,999$ & $17.5 \%$ & $4.0 \%$ & \\
\hline & $\$ 100,000+$ & $13.3 \%$ & $11.1 \%$ & \\
\hline
\end{tabular}

${ }^{*} p<0.05$ (less than $5 \%$ ), $* * p<0.01$ (less than $1 \%$ ). 
Table 3. Logistic Regression Results for the Likelihood of Adoption of Organic Farming Practices

\begin{tabular}{|c|c|c|c|c|}
\hline Independent Variables & $\begin{array}{l}\text { Expected } \\
\text { Sign }\end{array}$ & Model 1 & Model 2 & Model 3 \\
\hline Environmental concern & + & $\begin{array}{l}0.487 * * \\
(0.234)\end{array}$ & $\begin{array}{c}0.394 \\
(0.252)\end{array}$ & $\begin{array}{c}0.292 \\
(0.267)\end{array}$ \\
\hline Economic constraints & - & $\begin{array}{l}-0.639 * * * \\
(0.234)\end{array}$ & $\begin{array}{l}-0.700 * * * \\
(0.256)\end{array}$ & $\begin{array}{c}-0.493 * \\
(0.275)\end{array}$ \\
\hline Economic benefits & + & $\begin{array}{l}0.673 * * * \\
(0.241) \\
\end{array}$ & $\begin{array}{l}0.601 * * \\
(0.267) \\
\end{array}$ & $\begin{array}{c}0.518 * \\
(0.282) \\
\end{array}$ \\
\hline Risk tolerance & + & $\begin{array}{c}0.107 \\
(0.233)\end{array}$ & $\begin{array}{c}0.082 \\
(0.249)\end{array}$ & $\begin{array}{c}0.04 \\
(0.269)\end{array}$ \\
\hline Socialize & + & $\begin{array}{l}-0.231 * * \\
(0.116)\end{array}$ & $\begin{array}{c}-0.222 * \\
(0.129)\end{array}$ & $\begin{array}{c}-0.261 * \\
(0.136)\end{array}$ \\
\hline Gender & + & & $\begin{array}{c}0.701 \\
(0.432) \\
\end{array}$ & $\begin{array}{c}0.597 \\
(0.468) \\
\end{array}$ \\
\hline Income & + & & $\begin{array}{l}-0.303 * * \\
(0.150) \\
\end{array}$ & $\begin{array}{c}-0.252 \\
(0.160) \\
\end{array}$ \\
\hline Nonfarm employment & $? ?$ & & $\begin{array}{c}0.924 * \\
(0.485)\end{array}$ & $\begin{array}{c}0.954 * \\
(0.577) \\
\end{array}$ \\
\hline Years farming & - & & $\begin{array}{l}-0.038 * * \\
(0.017)\end{array}$ & $\begin{array}{c}-0.026 \\
(0.019)\end{array}$ \\
\hline \% income from farm & ?? & & $\begin{array}{c}0.012 \\
(0.009) \\
\end{array}$ & $\begin{array}{c}0.013 \\
(0.010) \\
\end{array}$ \\
\hline Farm size & + & & & $\begin{array}{l}-0.21 \\
(0.128)\end{array}$ \\
\hline Age & - & & & $\begin{array}{c}-0.014 \\
(0.020) \\
\end{array}$ \\
\hline Urban & + & & & $\begin{array}{c}0.615 \\
(0.467) \\
\end{array}$ \\
\hline Bachelors & + & & & $\begin{array}{c}0.498 \\
(0.472)\end{array}$ \\
\hline Ag. training & + & & & $\begin{array}{c}-0.187 \\
(0.450)\end{array}$ \\
\hline Constant & & $\begin{array}{l}0.809 * \\
(0.484) \\
\end{array}$ & $\begin{array}{r}1.212 \\
(0.827) \\
\end{array}$ & $\begin{array}{c}1.919 \\
(1.613) \\
\end{array}$ \\
\hline $\mathrm{N}$ & & 141 & 141 & 141 \\
\hline McFadden's R2 & & 0.145 & 0.23 & 0.267 \\
\hline Log-Likelihood & & -83.506 & -75.229 & -71.661 \\
\hline AIC & & 179.011 & 172.458 & 175.321 \\
\hline$\overline{\mathrm{BIC}}$ & & 196.704 & 204.894 & 222.502 \\
\hline Mean VIF & & 1.27 & 1.28 & 1.40 \\
\hline Correctly classified & & $71.63 \%$ & $80.85 \%$ & $78.72 \%$ \\
\hline
\end{tabular}

Standard errors are reported in parentheses.

${ }^{*} p<0.10$ (less than $\left.10 \%\right),{ }^{*} p<0.05$ (less than $5 \%$ ), $* * * p<0.01$ (less than $1 \%$ ).

better fit than model $2(\mathrm{LR}=7.136, \mathrm{df}=5$, $p=0.211)$. We argued ex ante above that model 2 was the best fit, and we find statistical support for this argument. As a result, model 2 parameter estimates are used in the remainder of the analysis, including marginal effect estimates and associated plots (Figures 1 and 2).

Marginal effects were calculated using model 2 parameters, with all continuous variables calculated at their mean (d=discrete change; ${ }^{*} p<0.10$, $* * p<0.05, * * * p<0.01)$. Broadly speaking, the results suggest that farmers choose to adopt organic practices on the basis of economic motives. Both economic constraints and economic benefits were significant and in the expected direction. The effects of economic benefits predicted probability of adopting organic practices as a function of perceived economic benefits through the interquartile range. It reveals, unsurprisingly, that a farmer is most likely ( $\sim 69$ percent) to adopt organic techniques when the perceived benefits are high and costs are low, and least likely ( $\sim 23$ percent) when these are reversed. At a given level of perceived economic benefits, the predicted probability of using organic farming methods declines by approximately 10 percent for each quartile change in perceived costs. Although the marginal effects of environmental motives and risk tolerance are positive, neither of these is statistically significant in models that contain controls (our preferred models). The most surprising finding, however, is that as a respondent's level of interaction with certified organic farmers increases, his or her likelihood of adopting organic practices declines. This result is robust across all three models.

Several contextual attributes are also relevant with respect to the organic farming decision. These include total household income, off-farm employ- 
ment, and the number of years an individual has been involved in the operation of a farm. As income increases, the likelihood of adopting organic farming techniques tends to decline, although as income from secondary sources increases, the likelihood of organic adoption increases. Approximately 60 percent of new farmers are predicted to adopt organic techniques, which falls to less than 50 and 30 percent after 20 and 40 years, respectively.

Research Question 2: How do farmers perceive USD A organic certification and what limits their pursuit of certification?

We asked participants about their opinions concerning interest in USDA organic certification. The battery contained 14 Likert-style items (measured on a 1 to 7 fully disagree to fully agree scale) and had a Cronbach's alpha value of 0.794 . The lack of availability of organic animal feed ranked highest, and when comparing the responses of the $\mathrm{CF}$ versus NCOF, a statistical difference was found with seven of the prompts and their respective scores. Table 4 details each item on the scale, the mean scores of the NCOF vs. the $\mathrm{CF}$, and the results of the oneway analysis of variance comparing $\mathrm{NCOF}$ and $\mathrm{CF}$ scores and the principal component analysis.

A principal component analysis (presented in Table 4) on the battery of questions detected the presence of three factors with eigenvalues greater than one (both had Cronbach's alpha score above .80). Bartlett's test of sphericity was significant at the .000 level with a KMO test for sample adequacy at .781. We used Bartlett's test to confirm the significance of the first PCA axis
Figure 1. Predicted Probability of Adopting Organic Farming Practices as a Function of Perceived Economic Benefits

Low, intermediate, and high are calculated as the 25th, 50th, and 75th percentile. All other values are held at their mean using model 2 parameters.

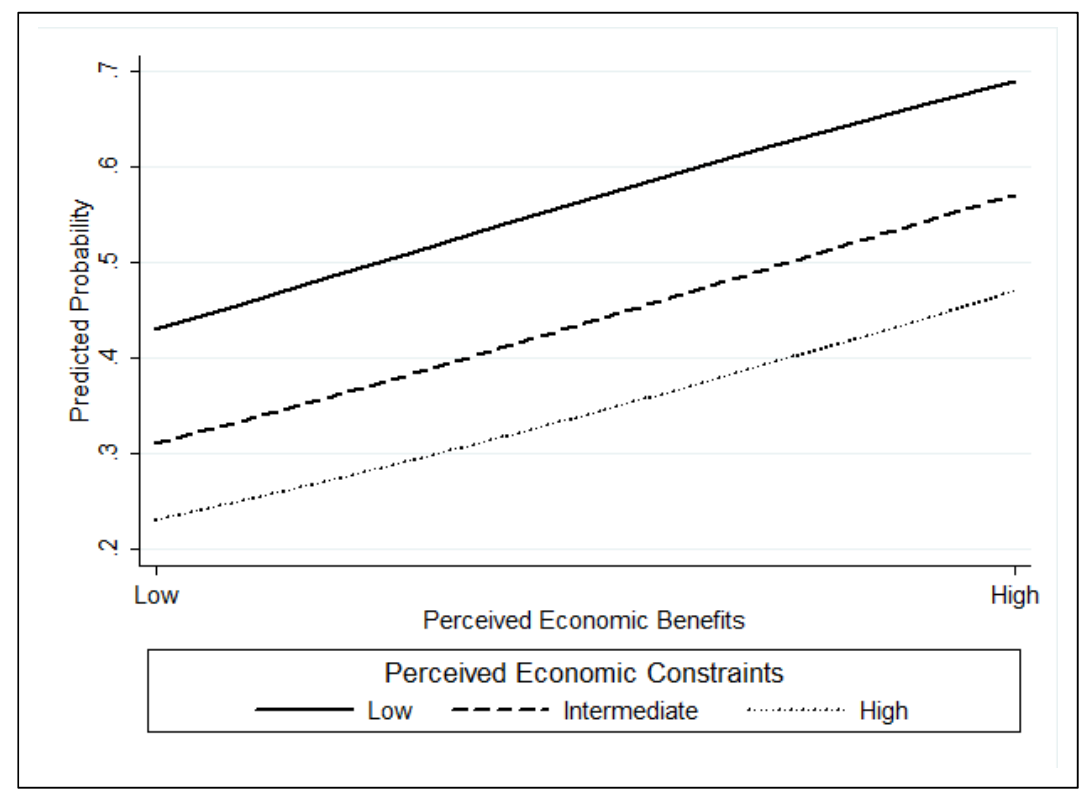

Figure 2. Predicted Probability of Adopting Organic Farming Practices as a Function of Socialization with Organic Farmers All other variables are held at their mean using model 2 parameters.

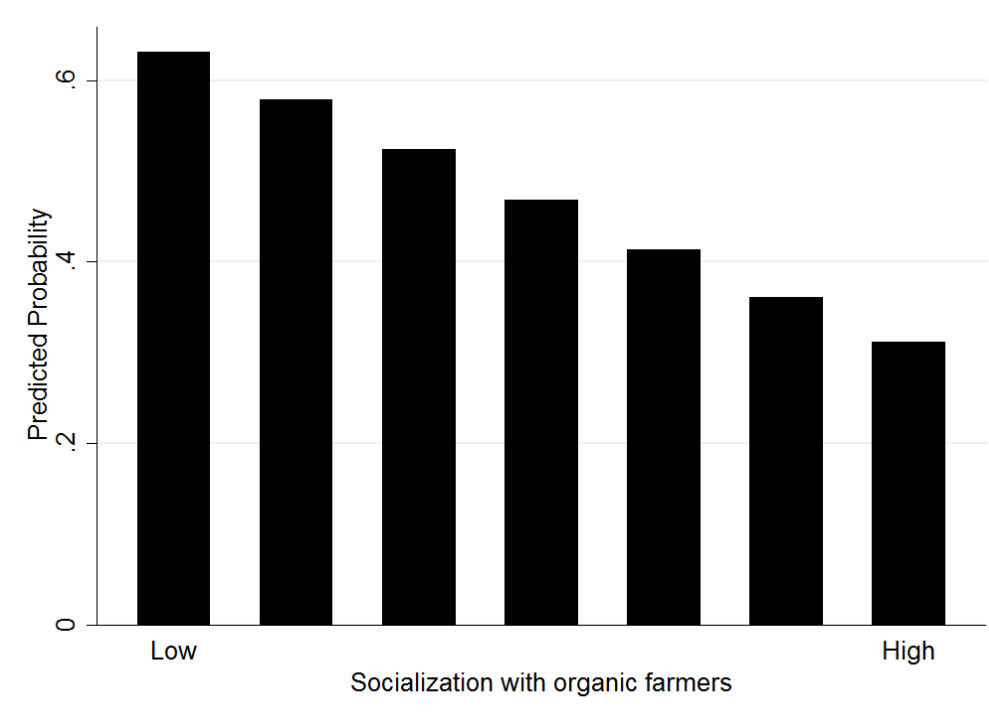

and the broken-stick rule to determine how many additional axes to interpret (Jackson, 1993; Legendre \& Legendre, 1998). The broken-stick approach can overestimate dimensionality (PeresNeto, Jackson, \& Somers, 2005); we chose to err in 
the direction of higher dimensionality. The two factors are named based on the factors with heavy loading at .300 or greater. Factor 1 had a Cronbach's alpha score of .830 and explained 28.93 percent of the variance. Factor 1 items were related to a lack of interest in organic methods, interest in government certifications or programs, learning and/or changing farming methods, and lack of interest among one's sales outlets; we entitled factor 1 no interest in the organic business. Factor 2 had a Cronbach's alpha score of .809 and explained 22.56 percent of the variance. This factor included a perception that the certification process was extremely time-consuming and expensive, animal feeds were hard to get, the benefits were not worthwhile, and the certification had little meaning; we entitled factor 2 process and perspective barriers.

\section{Discussion}

Our study sought to develop a better understanding of the factors that affect the adoption of organic practices and barriers to organic certification among specialty crop producers in West Virginia. Farmers in West Virginia face similar pressures and challenges as other farmers growing in similar mountainous, rural areas with geographic barriers to market outlets. This study presents a quantitative assessment of U.S. (West Virginian) organic farmers' choice to pursue organic management and a first step towards the use of a socialecological system approach to inform a more inclusive model of organic farming decisions.

Table 4. ANOVA and PCA Results from Likert Scale Assessing Interest in Pursuing Organic Certification and Production

\begin{tabular}{|c|c|c|c|c|c|}
\hline Prompt & NCOF Mean & CF Mean & ANOVA & Factor 1 & Factor 2 \\
\hline $\begin{array}{l}\text { - I have no interest in using organic methods for } \\
\text { production on my farm. }\end{array}$ & 1.67 & 3.36 & $.000 * *$ & .882 & -.074 \\
\hline $\begin{array}{l}\text { - I simply have no interest in organic production or } \\
\text { methods. }\end{array}$ & 1.60 & 3.58 & $.000 * *$ & .857 & -.069 \\
\hline $\begin{array}{l}\text { - Organic farming practices are not effective/practical for } \\
\text { my crop(s). }\end{array}$ & 2.07 & 4.03 & $.000 * *$ & .737 & .032 \\
\hline $\begin{array}{l}\text { - The individuals that purchase my farm products would } \\
\text { not pay for food grown/raised using organic methods. }\end{array}$ & 3.12 & 4.43 & $.000 * *$ & .637 & .134 \\
\hline $\begin{array}{l}\text { - I have no interest in learning about new farming } \\
\text { techniques that would be required to pursue USDA } \\
\text { organic certification. }\end{array}$ & 2.70 & 3.33 & $.044 *$ & .568 & .282 \\
\hline $\begin{array}{l}\text { - I am using practices that far surpass the USDA organic } \\
\text { certification requirements. }\end{array}$ & 4.69 & 2.89 & $.000 * *$ & -.502 & .169 \\
\hline $\begin{array}{l}\text { - I have no interest in changing the management systems } \\
\text { already in place on my farm. }\end{array}$ & 3.09 & 3.56 & .109 & .445 & -.040 \\
\hline $\begin{array}{l}\text { - I am not interested in government certifications or } \\
\text { programs. }\end{array}$ & 4.36 & 4.51 & .648 & .325 & .226 \\
\hline $\begin{array}{l}\text { - I find the USDA organic certification process extremely } \\
\text { time consuming. }\end{array}$ & 5.20 & 4.91 & .289 & -.035 & .833 \\
\hline $\begin{array}{l}\text { - I believe the costs associated with becoming USDA- } \\
\text { certified organic to be extremely high. }\end{array}$ & 5.25 & 5.13 & .671 & .103 & .782 \\
\hline $\begin{array}{l}\text { - I do not believe the benefits associated with USDA } \\
\text { organic certification are worth the time and expense. }\end{array}$ & 5.12 & 4.72 & .198 & .160 & .685 \\
\hline $\begin{array}{l}\text { - Availability of organic animal feed is a challenge for } \\
\text { raising livestock organically. }\end{array}$ & 5.74 & 5.53 & .532 & -.073 & .684 \\
\hline $\begin{array}{l}\text { - I find maintaining the certification paperwork extremely } \\
\text { time consuming. }\end{array}$ & 5.42 & 4.98 & .132 & .007 & .606 \\
\hline $\begin{array}{l}\text { - I feel that the organic certification by the USDA has been } \\
\text { co-opted and is no longer meaningful. }\end{array}$ & 5.16 & 4.02 & $.000 * *$ & -.136 & .439 \\
\hline
\end{tabular}

$* p<.05$ level, $* * p<.01$ 
Our survey results indicate that NCOF in the study are generally more concerned about the production of "high-quality foods" and the fertility and "health of the land" they farm than their conventional counterparts. In addition, risk attributes assessed in the survey indicated a self-reported willingness to take greater risks in farm management practices for those classified as NCOF. These findings parallel those of Koesling et al. (2004), who found that Norwegian organic crop farmers have a heightened willingness to assume risks when adopting farm management strategies.

Beyond noting that constraints were significant, the results parallel prior research that highlights the differences between conventional and organic farmers. Noncertified organic farmers in our study were younger and more often included females in operational decisions, had farm smaller acreages, had higher levels of education, had greater access to the Internet and used it for farming purposes, and grew up in urban or suburban areas when compared to CFs. These findings correspond to previous findings in the organic literature that found parallel results in studies that compared organic to conventional farmers (Burton et al., 1999; Veldstra et al., in press; Walz, 2004).

The results of our research contribute three particularly salient findings that merit additional discussion: (1) perception of economic benefits associated with organic production are as consequential for choice as perceived economic constraints; (2) although many farmers practice organic production, perceptions of the organic certification process and its components limit certification; and

(3) knowing an organic farmer seems to undermine the adoption of organic practices.

The choice to adopt organic production and certification is often viewed in terms of constraints (Veldstra et al., in press). Studies tend to begin with the assumption that given higher economic returns and positive environmental externalities that all farmers would choose to farm organically (unless one or more factors acted to constrain their transition). Our research demonstrates, however, that at least in the case of West Virginia, the effects of perceived economic benefits are as critical as the perceived effects of economic constraints. Cranfield et al. (2010) shared a similar finding, noting that, "the profit motive has become a more important factor underlying the decision to convert in recent times" (p. 304). Specifically, our results indicate that the choice to farm using organic techniques also depends upon a belief, whether founded or not, that the production of organic products will generate additional economic benefits. Clearly not all farmers in West Virginia hold this belief, and in West Virginia efforts by organic proponents to limit barriers and constraints are likely to have little effect on farming decisions unless accompanied by a perception of increased economic benefits.

Nonetheless, our analysis indicates potential constraints that may inhibit the pursuit of USDA organic certification. Data from many respondents suggest that farmers are skeptical or do not find a good fit with the program. As multiple farmers noted in the survey, they are pursuing certifications that parallel the USDA organic label. Specifically, question 25, an open-ended question, provided equally strong themes relating to positive and negative perspectives of USDA organic; some individuals felt that a product bearing the USDA Organic logo has met the strictest standards currently available for organic food, while just as many perceived it to be not necessarily sustainable and only useful for commercial-scale organic production and operations.

The most surprising result of this research was that increasing levels of socialization with certified organic farmers reduces the likelihood of transitioning to organic production. This in turn suggests that certified organic farmers may not be seeing increased revenues. If this is the case it may correspond to a general absence of pro-organic social norms and attitudes in West Virginia, which in a sense is a lack of market. It is also possible that current organic producers do not experience or at least share positive economic results with their peers, and thus provide information that may undermine transitions to organic production within a group of farmers. As noted in Cranfield et al. (2010), the lack of social acceptance in relation to organic practices may be a "significant problem and challenge" (p. 304) to adopting organic management systems where negative pressures seem insurmountable. Finally, the vast majority of 
our participants had small farms and distributed their farm products directly to consumers as opposed to selling through a food hub or to a wholesale distributorship. This result is similar to Torres, Marshall, and Alexander's (2013) recent findings of noncertified organic farmers. As they note, the need to certify tends to increase as the relationship between the farmer and the consumer is minimized or severed, which is often the case when wholesale distribution is utilized. Without the farmer-consumer relationship, price premiums and sales are less likely to be realized without a wellknown organic label such as the USDA certification logo (Janssen \& Hamm, 2012). Where our results diverge from Torres et al. (2013) is with their finding that the probability of certifying increases as one is further removed from the market. For our study, it may be the case that the rural areas of West Virginia are too far removed with no real access to an aggregation and distribution facility.

Our analysis adds to the discourse on environmental decision-making as it relates to sustainable agriculture. While the results regarding farmer's choices in West Virginia are interesting in and of themselves, their most significant contribution is to situate the choice of organic production in the context of a complex social-ecological system (Ostrom, 2007, 2009). Farmers in West Virginia, who are often operating under marginal conditions and serving limited local markets, are clearly different from California's massive agricultural industry or the cornfields of Indiana. Given these rather obvious differences, neither academic scholars nor policy-makers should be surprised to find that some attributes of the social, ecological, and institutional environments have different effects in different settings, and especially that policies that succeed in one setting may utterly fail in others (Acheson, 2006; Brock \& Carpenter, 2007). The USDA organic certification system does not appear to fit in the context of West Virginia, given that few farmers who actually adopt organic production go on to pursue certification. Many years of research on social-ecological systems have revealed that the effects of policies designed to enhance prospects for sustainability often depend critically upon how they interact with the context in which they are implemented (Acheson, 2006; Basurto \& Ostrom, 2009). The USDA certification process presents a nationwide model to encourage organic production, but in doing so its framers may be neglecting how these policies operate in varied contexts and thereby be undermining its goals. In other words, our results highlight that a one-sizefits-all approach might not necessarily fit all.

The results of our study have two primary implications for agriculture and food system professionals. First, the results indicate that, at least in the case of West Virginia farmers, the lack of perceived benefits to organic farming is as consequential as the prospect of economic returns. In other words, conventional farmers and/or potentially new or beginning farmers did not perceive enough potential benefits of farming using organic methods. This may be due to a number of reasons, but as indicated in our results the possible distribution options are likely a critical factor. Working to develop aggregation and distribution mechanisms for rural farmers is critical in order to shepherd the product to a viable market that has a critical mass for demand of organic products. Second, our results indicate a lack of overall interest by our study participants in pursuing USDA organic certification. Given the size and production of the farmers in our study compared to those certified elsewhere in the southeastern region of the U.S., size and scale of the farm does seem to matter, as small farmers appear to have less interest in and need for organic certification. If agricultural groups and agencies seek to increase the number of USDA-certified organic farms, working with farmers to increase the scale of their operation or with farmers already producing at a larger scale (that would warrant wholesale-style distribution) to transition to organic certification would likely prove most fruitful.

There are several limitations to this work. First, the sample is limited to mostly specialty crop producers in West Virginia and has no observations of USDA-certified organic farmers. Based on the 2007 USDA Agricultural Census, we expected that 70 or more organic farms would exist in West Virginia in 2012. This was a false assumption, as the current number of certified farms in West Virginia stands at five (based on the Charleston, 
West Virginia, USDA field office). A third limitation of this study is in the response rate (29.2 percent). Though well within an acceptable level for mailed surveys (Brown, 2004; Farmer, Knapp, Meretsky, Chancellor, \& Fischer, 2011), we feel our response rate was reduced because the USDA was conducting a survey during the same months that our phase 2 (mailed survey) collection process was occurring. Another limitation is that respondents self-selected their classification status (noncertified organic, conventional, in transition, or organic exempt) and there was no real mechanism for confirming this information without conducting on-the-farm visits.

Given our low number of respondents who classified themselves as transitioning or organic exempt, we were not able to statistically test the similarity between the two groups with each other or those classified as noncertified organic. This study's results by and large pertain to West Virginia, although the results do provide further insight into the factors that affect the decision to farm organically and to engage in the USDA organic certification process. Although we do not expect that our results are generalizable to all farms in the United States or those far from central Appalachia, we suggest that the results may be generalizable to the range of the independent variables (King, Keohane, \& Verba, 2001) that are within contexts similar to those found in West Virginia.

West Virginia is not a leading producer of agricultural products, whether organic or not, and is likely overlooked when national agriculture policy and environmental policies dealing with agriculture are designed. The lack of fit between the policy and West Virginia is quite clearly demonstrated by the near absence of certified organic farms. Nevertheless, the results also show that there are many farmers using organic practices in West Virginia and that new farmers who perceive a combination of high economic benefits and lower constraints are likely to choose to farm using organic methods. Further research is needed to build upon this work, using larger datasets at the regional or national scale in order to test the usefulness of context in understanding the decision to farm organically.

\section{Acknowledgments}

Foremost, we thank the farmers who took the time to participate in the telephone interviews and complete the mailed questionnaires. This project would not have been possible without their input. We also greatly appreciate the feedback we received on the questionnaire and interview scripts from farmer Tim Alexander, Dr. Tim Woods, farmer Dominique Wong, farmer Dr. Jennifer Meta-Robinson, Dr. Jim Kotcon, Laura Hartz, Megan Grandfield, and Anne Stroud. We thank M. Koesling for sharing his scales and batteries on evaluating intention to manage farms organically, Patricia Lezotte for editing assistance, and Downstream Strategies for their partnership in the research project. We appreciate the JAFSCD reviewers and their helpful feedback that greatly improved the article. Finally, we thank the United States Department of Agriculture, National Institute of Food and Agriculture (USDA-NIFA) for financial support of this project.

\section{References}

Acheson, J. M. (2006). Institutional failure in resource management. Annual Review of Anthropology, 35(1), 117-134. http://dx.doi.org/10.1146/annurev. anthro.35.081705.123238

Basurto, X., \& Ostrom, E. (2009). Beyond the tragedy of the Commons. Economia Delle Fonti di Energia e Dell'ambiente, 52(1), 35-60.

Brock, W. A., \& Carpenter, S. R. (2007). Panaceas and diversification of environmental policy. Proceedings of the National Academy of Sciences, 104(39),1520615211. http://dx.doi.org/10.1073/pnas.0702096104

Brophy, J. T., Keith, M. M., Watterson, A., Park, R., Gilbertson, M., Maticka-Tyndale, E.,...Luginaah, I. (2012). Breast cancer risk in relation to occupations with exposure to carcinogens and endocrine disruptors: A Canadian case-control study. Environmental Health, 11(1), 87. http://dx.doi.org/10.1186/1476-069X-11-87

Brown, G. (2004). Mapping spatial attributes in survey research for natural resource management: Methods and applications. Society and Natural Resources, 18(1), 17-39. http://dx.doi.org/10.1080/08941920590881853 
Burton, M., Rigby, D., \& Young, T. (1999). Analysis of the determinants of adoption of organic horticultural techniques in the UK. Journal of Agricultural Economics, 50(1), 47-63. http://dx.doi.org/10.1111/j.1477-9552. 1999.tb00794.x

Constance, D. H., \& Choi, J. Y. (2010). Overcoming the barriers to organic adoption in the United States: A look at pragmatic conventional producers in Texas. Sustainability, 2(1), 163-188. http://dx.doi.org/10.3390/su2010163

Cranfield, J., Henson, S. \& Holliday, J. (2010). The motives, benefits, and problems of conversion to organic production. Agriculture and Human Values, 27(3), 291-306. http://dx.doi.org/10.1007/s10460$\underline{009-9222-9}$

Crawford, S. E. S., \& Ostrom, E. (1995). A grammar of institutions. American Political Science Review, 89(3), 582-600. http://dx.doi.org/10.2307/2082975

Creswell, J. W., \& Plano Clark, V. L. (2007). Designing and conducting mixed methods research. Thousand Oaks, California: SAGE.

Darnhofer, I., Schneeberger, W., \& Freyer, B. (2005). Converting or not converting to organic farming in Austria: Farmer types and their rationale. Agriculture and Human Values, 22(1), 39-52. http://dx.doi.org/10.1007/s10460-004-7229-9

de Buck, A. J., van Rijn, I., Roling, N. G., \& Wossink G. A. A. (2001). Farmers' reasons for changing or not changing to more sustainable practices: An exploratory study of arable farming in the Netherlands. Journal of Agricultural Education and Extension, 7(3), 153-166. http://dx.doi.org/10.1080/13892240108438817

DeSouza Filho, H. M., Young, T., \& Burton, M. P. (1999). Factors influencing the adoption of sustainable agricultural technologies: Evidence from the state of Espírito Santo, Brazil. Technological Forecasting and Social Change, 60(2), 97-112. http://dx.doi.org/10.1016/S0040-1625(98)00040-7

Dillman, D. A., Smyth, J. D., \& Christian, L. M. (2009). Internet, mail, and mixed-mode surveys: The tailored design method (3rd ed.). Hoboken, New Jersey: Wiley.

Dimitri, C. \& Oberholtzer, L. (2009). Marketing U.S. organic foods: Recent trends from farms to consumers (Economic Information Bulletin No. EIB-58). Washington, D.C.: USDA, Economic Research
Service. Retrieved from http://www.ers.usda.gov/ publications/eib-economic-informationbulletin/eib58.aspx\#.U9rw1aMzRyw

Fairweather, J. R. (1999). Understanding how farmers choose between organic and conventional production: Results from New Zealand and policy implications. Agriculture and Human Values, 16(1), 51-63. http://dx.doi.org/10.1023/A:1007522819471

Farmer, J. R., Knapp, D., Meretsky, V. J., Chancellor, C., \& Fischer, B. C. (2011). Motivations influencing the adoption of conservation easements. Conservation Biology, 25(4), 827-834. http://dx.doi.org/10.1111/ j.1523-1739.2011.01686.x

Farmer, J., Peters, C., Hanson, E., \& Boettner, E. (2013). Overcoming the market barriers to organic production in West Virginia (USDA-NIFA grant final report). Available at http://www.downstream strategies.com/documents/ reports publication/ overcoming market barriers to organic production in wv.pdf

Gardebroek, C. (2006). Comparing risk attitudes of organic and non-organic farmers with a Bayesian random coefficient model. European Review of Agricultural Economics, 33(4), 485-510. http://dx.doi.org/10.1093/erae/jbl029

Gintis, H. (2009). The bounds of reason: Game theory and the unification of the behavioral sciences. Princeton, New Jersey: Princeton University Press.

Greene, J. C., Caracelli, V. J., \& Graham, W. F. (1989). Toward a conceptual framework for mixed-method evaluation designs. Educational Evaluation and Policy Analysis, 11(3), 255-274. http://dx.doi.org/10.3102/01623737011003255

Hall, A., \& Mogyorody, V. (2007). Organic farming, gender, and the labor process. Rural Sociology, 72(2), 289-316. http://onlinelibrary.wiley.com/ journal/10.1111/\%28ISSN\%291549-0831

Hardwaker, J. B., Huirne, R. B. M., Anderson, J. R., \& Lien, G. (2004). Coping with risk in agriculture (2nd ed.). Wallingford, UK: CAB International. http://dx.doi.org/10.1079/9780851998312.0000

Henning, J., Baker, L., \& Thomassin, P. (1991). Economics issues in organic agriculture. Canadian Journal of Agricultural Economics, 39(4), 877-889. http://dx.doi.org/10.1111/j.17447976.1991.tb03649.x 
Hole, D. G., Perkins, A. J., Wilson, J. D., Alexander, I. H., Grice, P. V., \& Evans, A. D. (2005). Does organic farming benefit biodiversity? Biological Conservation, 122(1), 113-130. http://dx.doi.org/10.1016/j.biocon.2004.07.018

Jackson, D. A. (1993). Stopping rules in principal components analysis: A comparison of heuristical and statistical approaches. Ecology, 74(8), 2204 2214. http://dx.doi.org/10.2307/1939574

Janssen, M., \& Hamm, U. (2012). Product labelling in the market for organic food: Consumer preferences and willingness-to-pay for different organic certification logos. Food Quality and Preference, 25(1), 9-22. http://dx.doi.org/10.1016/j.foodqual.2011.12.004

King, G., Keohane, R. O., \& Verba, S. (2001). Designing social inquiry: Scientific inference in qualitative research. Princeton, New Jersey: Princeton University Press.

Klonsky, K. (2012). Comparison of production costs and resource use for organic and conventional production systems. American Journal of Agriculture Economics, 94(2), 314-321. http://dx.doi.org/10.1093/ajae/aar102

Koesling, M., Ebbesvik, M., Lien, G., Flaten, O., Steiner, P., \& Arntzen, H. (2004). Risk and risk management in organic and conventional cash crop farming in Norway. Food Economics, 1(4), 195-206. http://dx.doi.org/10.1080/16507540410019692

Kuminoff, N. V., \& Wossink, A. (2010). Why isn't more US farmland organic? Journal of Agricultural Economics, 61(2), 240-258. http://dx.doi.org/10. $1111 / \mathrm{j} .1477-9552.2009 .00235 . \mathrm{x}$

Läpple, D. (2013). Comparing attitudes and characteristics of organic, former organic and conventional farmers: Evidence from Ireland. Renewable Agriculture and Food Systems, 28(4), 329337.

http://dx.doi.org/10.1017/S1742170512000294

Legendre, P., \& Legendre, L. (1998). Numerical ecology (3rd ed.). Amsterdam: Elsevier.

Organic Trade Association [OTA]. (2011). Organic industry survey executive summary. Washington, DC: Author. Retrieved from http://www.ota.com/ pics/documents/OTA2011IndustrySurveyExec Summary.pdf

Ostrom, E. (1998). A behavioral approach to the rational choice theory of collective action. American Political Science Review, 92(1), 1-22. http://dx.doi.org/10.2307/2585925
Ostrom, E. (2007). A diagnostic approach for going beyond panaceas. Proceedings of the National Academy of Sciences, 104(39), 15181-15187. http://dx.doi.org/10.1073/pnas.0702288104

Ostrom, E. (2009). A general framework for analyzing sustainability of social-ecological systems. Science, 325(5939), 419-422. http://dx.doi.org/10.1126/science.1172133

Ostrom, E., \& Cox, M. (2010). Moving beyond panaceas: A multi-tiered diagnostic approach for social-ecological analysis. Environmental Conservation, 37(4), 451-463. http://dx.doi.org/10.1017/S0376892910000834

Padel, S. (2001). Conversion to organic farming: A typical example of the diffusion of an innovation? Sociologia Ruralis, 41(1), 40-61. http://dx.doi.org/10.1111/1467-9523.00169

Peres-Neto, P. R., Jackson, D. A., \& Somers, K. M. (2005). How many principal components? Stopping rules for determining the number of non-trivial axes revisited. Computational Statistics and Data Analysis, 49(4), 974-997. http://dx.doi.org/10.1016/j.csda.2004.06.015

Pimentel, D., Hepperly, P., Hanson, J., Douds, D., \& Seidel, R. (2005). Environmental, energetic, and economic comparisons of organic and conventional farming systems. BioScience, 55(7), 573-582. http://dx.doi.org/10.1641/0006-3568(2005) 055\%5B0573:EEAECO \%5D2.0.CO;2

Posner, R. A. (1997). Social norms and the law: An economic approach. American Economic Review, 87(2), 365-369.

Poteete, A. R., Janssen, M. A., \& Ostrom, E. (2010). Working together: Collective action, the Commons, and multiple methods in practice. Princeton, New Jersey: Princeton University Press.

Raftery, A. E. (1995). Bayesian model selection in social research. Sociological Methodology, 25, 111-163. http://dx.doi.org/10.2307/271063

Ramcilovic-Suominen, S. \& Epstein, G. (2012). Towards an analytical framework for forest law compliance. International Forestry Review, 14(3), 326-336. http://dx.doi.org/10.1505/146554812802646611

Reganold, J. P., Glover, J. D., Andrews, P. K., \& Hinman, H. R. (2001). Sustainability of three apple production systems. Nature, 410, 926-930. http://dx.doi.org/10.1038/35073574 
Richards, T. J., Acharya, R. N., \& Molina, I. (2011). Retail and wholesale market power in organic apples. Agribusiness: An International Journal, 27(1), 62-81. http://dx.doi.org/10.1002/agr.20251

Sierra, L., Klonsky, K., Strochlic, R., Brodt, S. \& Molinar, R. (2008). Factors associated with deregistration among organic farmers in California. Davis, California: California Institute for Rural Studies. Retrieved from http://www.cirsinc.org/publications/ category/9-food-systems

Sullivan, S., Mccann, E., de Young, R., \& Erickson, D. (1996). Farmers' attitudes about farming and the environment: A survey of conventional and organic farmers. Journal of Agricultural and Environmental Ethics, 9(2), 123-143. http://dx.doi.org/10.1007/BF03055298

Svensson, I. (1991). Governmental subsidy to organic farming 1989: A mail inquiry. Alternativ-Odling, 7, 88-92.

Thilmany, D. (2006). The US organic industry: Important trends and emerging issues for the USD A (Agribusiness Marketing Report, ABMR 06-01). Fort Collins, Colorado: Colorado State University. Retrieved from http://organic.colostate.edu/documents/ Thilmany paper.pdf

Torres, A. P., Marshall, M. I., \& Alexander, C. E. (2013). Does proximity determine organic certification among farmers using organic practices? Paper presented at the 2013 annual meeting of the Agricultural \& Applied Economics Association, Washington, D.C. Retrieved from the AgEconSearch website: http://ageconsearch. umn.edu/bitstream/150607/2/Does $\% 20$ proximity $\%$ 20determine $\% 20$ organic $\% 20$ certification.pdf

Uematsu, H. \& Mishra, A. K. (2012). Organic farmers or conventional farmers: Where's the money?

Ecological Economics, 78, 55-62.

http://dx.doi.org/10.1016/j.ecolecon.2012.03.013

U.S. Department of Agriculture [USDA]. (2007a). 2007

Census of Agriculture: Small farms. USDA, National

Agriculture Statistics Service. Retrieved from http://www.agcensus.usda.gov/Publications/2007 /Online Highlights/Fact Sheets/Farm Numbers/ small farm.pdf

USDA. (2007b). Historical highlights: 2007 and earlier Census Years: West Virginia [Table 1]. Retrieved from http://www.agcensus.usda.gov/Publications/ 2007/Full Report/Volume 1, Chapter 1 State Level/West_Virginia/st54_1_001_001.pdf

USDA. (2013). Commodity areas: Definition of specialty crops. USDA, Agricultural Marketing Service. Retrieved from http://www.ams.usda.gov/AMSv1.0/ $\underline{\text { scbgpdefinitions }}$

Veldstra, M. D., Alexander, C. E., \& Marshall, M. I. (in press). To certify or not to certify? Separating the organic production and certification decisions. Food Policy. Retrieved from http://www.sciencedirect. com/science/article/pii/S0306919214000840

Walz, E. (2004). Final results of the fourth national organic farmers' survey: Sustaining organic farms in a changing organic marketplace. Santa Cruz, California: Organic Farming Research Foundation. Retrieved from http://www.ofrf.org/sites/ofrf.org/files/docs/ pdf/4thsurvey results.pdf

Wortman, S. E., Francis, C. A., Bernards, M. L., Drijber, R. A., \& Lindquist, J. L. (2012). Optimizing cover crop benefits with diverse mixtures and an alternative termination method. Agronomy Journal, 104(5), 1425-1435. http://dx.doi.org/10.2134/agronj2012.0185 